\title{
Creation of a financial mechanism for ensuring sustainable economic growth of business in the context of global challenges
}

\author{
Gaukhar Kodasheva ${ }^{1}$, Nadezda Piontkevich ${ }^{2,}$, and Ekaterina Sheina ${ }^{2}$ \\ ${ }^{1}$ Eurasian National University named after L.N. Gumilyov, 010000, Kanysha Satpayeva str, 2A, Nur- \\ Sultan, Kazakhstan \\ ${ }^{2}$ Ural State University of Economics, 620144, 8 Marta Str., 62, Ekaterinburg, Russia
}

\begin{abstract}
The vector of development of the Russian economy, which is aimed at sustainable economic growth of business, was threatened by unforeseen circumstances - the new coronavirus pandemic, which turned out to be one of the most powerful global external challenges for all leading national economies and the global business community as a whole. To overcome and minimize the consequences of the pandemic in the form of protracted economic crisis, the fall of the Russian currency, slow reproductive processes, a sharp decline in incomes and rise in unemployment, the almost complete stop of activities of business entities and investment processes, it is necessary for a state to take responsibility to stabilize the economy and rapid sustainable growth through the development and prompt implementation of a comprehensive plan for effective emergency measures to support the business, based on the implementation of which the authors propose a financial mechanism for ensuring sustainable economic growth of business.
\end{abstract}

\section{Introduction}

As the experience of overcoming the consequences of the previous economic crises of 1998 and 2008 shows, the most important is the timely targeted support of the state for small and medium-sized businesses, as the basis for the formation of a middle class of society that can create and maintain jobs, including providing employment for family members, which is the most tangible method in the fight against unemployment in small municipalities and urban districts. It is also generally recognized that small and medium-sized enterprises are stable payers of taxes to budgets of all levels and initiators of innovative development of society, so maintaining financial stability and financial security of these business entities determines the sustainable economic growth of the country as a whole.

In response to the global challenge of the coronavirus pandemic and quarantine measures that brought economic processes to a standstill in 2020, the government of the Russian Federation has developed several legislative acts regulating the implementation of urgent measures to support small and medium-sized businesses.

\footnotetext{
${ }^{*}$ Corresponding author: nspiont@gmail.com
} 


\section{Materials and methods}

Methodological base of research is built on the theory of finance and management theory, and problem oriented approach, tailored to the complexity of finding funding sources at all stages of the life cycle of the enterprises of small and medium businesses of all sectors and forms of ownership, especially in the context of global challenges and the need to minimize financial risks.

The materials of the study are legislative acts of the government of the Russian Federation regulating the distribution of federal budget funds for urgent measures to support small and medium-sized businesses in the context of a worsening situation due to the spread of a new coronavirus infection in 2020, as well as operational statistics from the Ministry of economic development of the Russian Federation in period from April 01 to September 13, 2020.

Among the set of urgent measures to support small and medium-sized businesses, implemented by the state: information, consulting, infrastructure, financial and other measures, the authors highlight such urgent financial support measures as guarantees for bank loans / guarantees and the provision of microloans, as the most effective stimulating liquidity, supporting financial stability and providing access to debt financing for small and medium-sized enterprises.

In the course of the study, the authors use methods of dialectical, cause-and-effect and structural-logical analysis, which allows to streamline the theoretical aspects of microfinance and the provision of guarantees for bank loans / guarantees as possible alternative sources of loan financing for business in the Russian Federation during the crisis.

The research hypothesis is based on the idea of the relationship between the term for the provision of borrowed resources and the rate of recovery of stable financial performance indicators in the long term, which makes it possible to move from formulating a general problem to identifying the advantages and disadvantages of specific conditions for providing the above urgent measures of financial support to small and medium-sized businesses.

\section{Results and Discussion}

Urgent measures of financial support in the form of guarantees for bank loans / guarantees and microloans in 2020, financed from the Reserve Fund of the government of the Russian Federation and the national project "Small and medium enterprises and support for individual entrepreneurial initiatives" are characterized by certain conditions (Table 1).

Table 1. Conditions for the implementation of urgent measures to support small and medium-sized businesses [1]

\begin{tabular}{|l|c|c|}
\hline $\begin{array}{c}\text { Conditions for the } \\
\text { provision of urgent } \\
\text { measures }\end{array}$ & $\begin{array}{c}\text { Providing sureties for bank loans } \\
\text { / guarantees }\end{array}$ & Providing microloans \\
\hline $\begin{array}{l}\text { Application } \\
\text { consideration period }\end{array}$ & \multicolumn{2}{|c|}{ No more than 1 week day } \\
\hline Interest rate & $\begin{array}{c}\text { Remuneration rate no more than } \\
0.5 \%\end{array}$ & $\begin{array}{c}\text { No more than a key rate } \\
\text { Central Bank of Russia }\end{array}$ \\
\hline $\begin{array}{l}\text { Maximum period of } \\
\text { provision }\end{array}$ & $\begin{array}{c}\text { No more than 3 years } \\
\text { No more than 2 years }\end{array}$ \\
\hline
\end{tabular}


Analyzing the data in table 1, we can conclude that urgent measures of financial support for small and medium-sized businesses in the context of the pandemic in the Russian Federation are primarily aimed at providing borrowed sources of financing to replenish working capital and replenish current liquidity, but these measures do not take into account the indefinite period of financial problems and the need for more significant and long-term (up to 5 years) financing with a significant period of deferred payments, this will allow to reduce the debt burden that is already high in the context of a decrease or complete absence of revenue.

Table 2 below shows data on the implementation of financial support urgent measures for small and medium-sized enterprises in the form of guarantees for bank loans/guarantees and microloans at the expense of the reserve Fund of the government of the Russian Federation in the amount of 2 billion rubles for the Russian Federation subjects, in the period from April 01 to September 13, 2020. Separately, data is provided for the ten regions of the Russian Federation that received the largest amount of funding under the presented support measures, of which the Sverdlovsk region ranks 1st.

Table 2. Implementation of urgent measures to support small and medium-sized businesses in the context of the pandemic at the expense of the reserve Fund of the government of the Russian Federation in 2020, thousand rubles [2,3]

\begin{tabular}{|c|c|c|c|c|}
\hline RF subject & $\begin{array}{c}\text { Subsidies plan } \\
\text { for the } \\
\text { provision of } \\
\text { guarantees }\end{array}$ & $\begin{array}{c}\text { Volume of } \\
\text { loans to small } \\
\text { and medium- } \\
\text { sized } \\
\text { businesses } \\
\text { with } \\
\text { guarantee } \\
\text { support }\end{array}$ & $\begin{array}{c}\text { Subsidies plan } \\
\text { for the } \\
\text { provision of } \\
\text { microloans }\end{array}$ & $\begin{array}{c}\text { Volume of } \\
\text { microloans } \\
\text { issued to } \\
\text { small and } \\
\text { medium - } \\
\text { sized } \\
\text { businesses }\end{array}$ \\
\hline Sverdlovsk region & 126093,50 & 342100,05 & 3639,60 & 5830,00 \\
\hline Primorsky Krai & 80920,10 & 199307,92 & 11474,10 & 18147,00 \\
\hline Republic of Tatarstan & 64294,40 & 155290,00 & 3343,30 & 4774,00 \\
\hline Ryazan Oblast & 50000,00 & 110000,00 & 10246,00 & 10246,00 \\
\hline Republic of Crimea & 49865,70 & 101000,00 & 6761,40 & 6761,40 \\
\hline Belgorod region & 44204,50 & 41875,00 & 4638,10 & 4638,10 \\
\hline $\begin{array}{c}\text { Nizhny Novgorod } \\
\text { Region }\end{array}$ & 39792,80 & 2400,00 & 16926,10 & 9360,00 \\
\hline Krasnodar region & 37670,30 & 31510,05 & 4823,90 & 4823,90 \\
\hline Penza region & 36485,90 & 0,00 & 11498,60 & 5490,00 \\
\hline $\begin{array}{c}\text { Jewish Autonomous } \\
\text { Region }\end{array}$ & 34267,10 & 0,00 & 24196,80 & 0,00 \\
\hline $\begin{array}{c}\text { Other subjects of the } \\
\text { Russian Federation }\end{array}$ & 436405,70 & 2686646,77 & 902452,10 & 663078,78 \\
\hline Total & 1000000,00 & 3670129,79 & 1000000,00 & 733149,18 \\
\hline
\end{tabular}

1 billion rubles have been allocated for the provision of bank loans/guarantees. The amount of loans/guarantees attracted to the small and medium-sized business sector is taken as the indicator of estimated effect, which is 3,670,129. 79 thousand rubles. Thus, 1 ruble of support from the Federal budget allowed to attract 3.60 rubles of funds from the loan capital market. The number of supported small and medium-sized businesses amounted to 329 units. For the provision of microloans, 1 billion rubles have been also allocated, of which 733,149. 18 thousand rubles have already been provided to 704 small and mediumsized businesses. The amount of microloans under the established conditions is no more 
than 500 thousand rubles, which does not solve the long - term necessary financial investments in the business in a crisis.

When implementing financial support measures, businesses need to receive feedback to further improve this activity and get the necessary results from it for all participants in the process. Thus, in unstable economic, political and other conditions, businesses need to be able, at least, to continue functioning in the market, while remaining a competitive business entity, and at most, to increase the efficiency of their activities. The authors suggest using a special mechanism for ensuring sustainable economic growth of business in the process of implementing financial measures of state support (Fig. 1)

\begin{tabular}{|l|l|}
\hline \multicolumn{2}{|c|}{ Financial measures of state support for business } \\
\hline \multicolumn{2}{|c|}{ Financial management of a business entity } \\
\hline \multicolumn{1}{|c|}{ Operational effect } \\
\begin{tabular}{|l|l|}
\hline \multicolumn{1}{|c|}{ - improvement of capital structure } \\
- reduction in the cost of borrowed \\
funding sources \\
- liquidity recovery \\
- strengthening financial stability \\
- increasing the profitability of activities
\end{tabular} & $\begin{array}{l}\text { Strategic effect } \\
\text { - strengthening of solvency } \\
\text { - business value growth } \\
\text { - increasing the competitiveness and } \\
\text { investment attractiveness of business }\end{array}$ \\
\hline
\end{tabular}

Fig. 1. Financial mechanism for ensuring sustainable economic growth of business $[4,5,6,7,8,9$, $10,11]$

For the state, the aspect of sustainable economic development as a whole is important, which is possible provided that actions are coordinated in the implementation of support measures between all levels of government, as well as the application of a targeted approach to the implementation of support for individual economic entities, taking into account not only short-term, but also long-term needs and development guidelines business..

Control over the achievement of operational and strategic financial parameters of the activities of business entities that have received financial measures of state support is a prerequisite for assessing the effectiveness of the implemented support measures and ensuring sustainable economic growth of business. Thus, the hypothesis of the study on the relationship between the term for the provision of borrowed resources and various time frames required to restore sustainable financial performance of business entities, stated by the authors, is confirmed.

\section{Conclusions}

Ensuring national economic development is undoubtedly the prerogative of state management of the economy, in connection with which, during the crisis period of economic development, state monetary support measures implemented by the Government of the Russian Federation acquire special significance. These measures act as a financial mechanism for ensuring sustainable economic growth of business. The success of the events and also the trajectory of further development of the national economy depends on how correctly the support mechanism is selected.

The subjective nature problems of a financial mechanism for ensuring sustainable economic growth of a business remain the following:

- communication between the state and business through meetings with representatives of large and super-large businesses; 
- the general mutual distrust between the authorities and business;

- fully unclaimed public-private partnership mechanism;

- weakness and inefficiency of the subjects of the business itself;

- underdevelopment of institutions and organizations of civil society;

- many measures are characterized by the risk of insufficient transparency of results, and in some cases - low transparency of decision-making procedures [12].

In general, the problems noted are still the constraints that determine the low efficiency of communication mechanisms between business and the government.

The measures of state support implemented by the Government of the Russian Federation and the principles of making appropriate decisions require improvement. Therefore, the implementation of a number of additional measures will make it possible to adequately counter the identified global challenges.

When assessing the effectiveness of ongoing support measures, attention should be paid to such aspects as:

- the tools used for the implementation of measures, their functional focus, validity periods, the amount of budget costs;

- compliance of measures with previously established long-term directions of state economic policy;

- comparison of the main groups of beneficiaries and losers from the implementation of measures;

- the motivational potential of measures, the presence of behavioral requirements;

- the main risks associated with increased uncertainty in the business environment, etc. [12].

To create an effective financial mechanism for ensuring sustainable economic growth of business in the face of global challenges, it is necessary to take into account all the identified shortcomings in the anti-crisis public administration system and build new approaches to interaction with business in the context of the growing interdependence of global and national interests.

\section{References}

1. Decree of the Government of the Russian Federation of March 31, 2020 No. 378 "On Amending the State Program of the Russian Federation" Economic Development and Innovative Economy "

2. Order of the Government of the Russian Federation dated April 30, 2020 No. 1192-r.

3. Official website of the Ministry of Economic Development of the Russian Federation, https://www.economy.gov.ru/

4. N.S. Piontkevich, E.G. Shatkovskaya, Proceedings of the First International Volga Region Conference on Economics, Humanities and Sports (FICEHS 2019)

5. E.G. Sheina, E.R. Zakirova, G.G. Tsoi, O.T. Astanakulov, Academy of Entrepreneurship J., 25(4) (2019)

6. B.M. Sabanti, T.Sh. Tinikashvili, Economics, monetary economy, finance: monograph (Publishing house of SOGU, 2011)

7. Yu. Brigham, M. Erhardt, Financial Management (St. Petersburg: Peter, 2007)

8. J. Pierce II, Strategic management (2013)

9. G.V. Savitskaya, Analysis of the economic activity of the enterprise: textbook (INFRAM, 2007) 
10. E.I. Shokhin, et al., Financial management: theory and practice: textbook (KNORUS, 2012)

11. Financial management: theory and practice: textbook, ed. E.S. Stoyanova (Publishing house "Perspective", 2005)

12. A.V. Makarov, O.B. Veretenikova, State support of industry in the context of cyclical development of the tourism economy in the region: monograph (Publishing house of the Ural State Economic University, 2012) 